


\title{
Collation Article
}

\section{Microplastics in Environment and Effects on Biota}

\section{Çevresel Ortamlarda Mikroplastikler ve Canlılara Etkileri}

\author{
Kübra Bozdaş ${ }^{1}$, Gökhan Ekrem Üstün ${ }^{1}$, Ahmet Aygün ${ }^{2, *}$ \\ ${ }^{1}$ University of Bursa Uludağ, Department of Environmental Engineering, Bursa, Turkey \\ ${ }^{2}$ Bursa Technical University, Department of Environmental Engineering, Bursa, Turkey \\ kbra.bozdas@hotmail.com (https://orcid.org/0000-0003-4921-2058),gokhaneu@uludag.edu.tr \\ (https://orcid.org/0000-0002-7126-6792), ahmet.aygun@btu.edu.tr (https://orcid.org/0000-0002- \\ 6321-0350) \\ Received Date:16.12.2019, Accepted Date: 17.07.2020 \\ DOI:10.31807/tjwsm.660146
}

\begin{abstract}
Plastics are used in many different fields because they are light, cheap and easy to process and become one of the most important commercial materials of today. The use of plastics is increasing every year, and since most of these materials are disposable and their wastes are not managed well, it brings environmental pollution problem. Particles smaller than $5 \mathrm{~mm}$ and known as microplastics are formed as a result of the breakdown of plastics by different processes in nature or as a result of direct use such as microbonces, textile fibers. Microplastics are ubiquitous in nature and are of concern for ecosystems. Environmental problems related with microplastic and studies on this subject have become the focus of interest in the last decade. Microplastics into receiving water from different sources poses a threat to aquatic organisms and humans. In this study, microplastics in different environments and their effects on environment and human health were reviewed.
\end{abstract}

Keywords: Microplastics, receiving body, health effect, pollution

\section{Öz}

Plastikler hafif, ucuz ve kolay işlenebilir olması sebebiyle çok farklı alanlarda kullanılmakta günümüzün en önemli ticari malzemelerinden birine dönüşmektedir. Plastik kullanımı her geçen yıl artmakta, bu malzemelerin çoğunun tek kullanımlık olması ve atıklarının iyi yönetilememesi sebebiyle çevre kirliliği problemini de beraberinde getirmektedir. Plastiklerin doğada farklı süreçlerle parçalanması sonucunda veya mikroboncuk, tekstil elyafları gibi doğrudan kullanım sonucu $5 \mathrm{~mm}$ 'den küçük olan ve mikroplastikler olarak bilinen parçacıklar oluşur. Mikroplastikler doğada her yerde bulunmakta ve çevresel ortamlar kadar canlı yaşamı için de kaygı uyandırmaktadır. Son on yılda mikroplastik kaynaklı çevre sorunları ve bu konuda yapılan çalışmalar ilgi odağı olmaya başlamıştır. Mikroplastiklerin farklı kaynaklardan su ortamlarına karışması, suda yaşayan canlılar ve insanlar için tehdit oluşturmaktadır. Bu çalışma kapsamında farklı ortamlarda bulunan mikroplastikler ile çevre ve insan sağlı̆̆ına olan etkileri değerlendirilmişsir.

Anahtar kelimeler: Mikroplastikler, alıcı ortam, sağlık etkisi, kirlilik

\footnotetext{
* Corresponding author
} 


\section{Introduction}

Plastics are known as light, strong, inexpensive and corrosion resistant materials having electrical insulation and high thermal properties. (Thompson et al., 2009). Due to the continuous improvement of the durability of plastics, it has become an indispensable product of today. Plastic consumption in the world has been increasing rapidly and exponentially since the 1950s. The use of plastics is estimated to reach 540 million tons by 2020, compared to 7 million tons in the 1960s (Pardos Marketing, 2019). Rochman et al. (2013a) predicted that if consumption continues at the same trend, plastics accumulation would be approximately 33 billion tonnes on the earth by 2050. Plastics are divided into polyethylene terephthalate (PET), polyamide (PA, nylon), polyester, polyethylene ( $\mathrm{PE})$, polypropylene $(\mathrm{PP})$, polystyrene (PS), polycarbonate (PC) and polyvinyl chloride (PVC) (Liu et al., 2019). PETs are sourced from personal care products, water bottles, food packaging films, while PAs are sourced from synthetic textile fibers and plastic bags. (Ngo et al., 2019).

Plastics are not biodegradable becuse of their high molecular weight, hydrophobicity and cross-linked chemical structure. Polymers of common use, such as polyethylene and polystyrene, are highly resistant to biological degradation (Horton et al., 2017). The most of the plastics produced are used as disposable packaging materials or short-lived products. Therefore, they are not environmental friendly materials (Hopewell et al., 2009). Plastics are commonly accumulated in the environment due to their durability, unsustainable usage and improper waste management (Barnes et al., 2009).

It is reported that approximately 4.8-12.7 million tonnes of plastics were accumulated in the oceans in 2010 which is stand for $5 \%$ of the plastic waste production (Jambeck et al., 2015). Plastic particles may float on the surface of oceans given as 5.25 trillion plastic particles equal to 268940 tonnes in one of the recent publication (Eriksen et al., 2014). Based on World Economic Forum report the amount of plastics in the oceans will exceed the weight of fish stocks by 2050 (WEF, 2016).

Microplastic (MP) pollution levels are higher in undeveloped areas due to large quantities of plastic entering the oceans by land due to inadequate waste management. According to 2010 estimates mismanaged waste plastic waste sorting in Turkey, it ranks $14^{\text {th }}$ in the world (Jambeck et al., 2015). In Europe, 70-130 thousand tons of plastics are thrown into the sea annually, and most of these plastics complete their journeys in the Mediterranean and constitute a threat to the marine ecosystem (WWF-Türkiye, 2018). Today, the plastic footprint is growing. Plastic bags known 
as difficult-to-decompose material, desposed to environment right after single usage since their inexpensive price results in environmental pollution for a long time (Wang et al., 2016). When plastic wastes are not disposed of safely, they accumulate in the environment and pose a threat to terrestrial and aquatic environments.

MPs are known as plastic particles smaller than $5 \mathrm{~mm}$ in size (Wright et al., 2013). The size classification of MPs are illustrated in Figure 1A. MPs are found everywhere in the marine environment, seawater surface and depth, from the equator to the poles, on the ocean and on the coast (Barnes et al., 2009). MPs are produced from primary and secondary sources shown in Figure 1B. Primary MPs contain PP, PE and PS particles found in personel care products (PPCPs) (Horton et al., 2017). Secondary MPs are the result of large plastics being disintegration into smaller pieces by sunlight, water, wind and other environmental factors (Sun et al., 2019). Primary sources are deliberately produced, such as washers, abrasives, and pellets, while secondary sources are caused by degradation of larger particles such as fragments and fibers (Desforges et al., 2014).

MP particles found in industry, personal care and cosmetic products are defined as micro beads (primary micro plastics). Approximately $93 \%$ of the microbeads contained in cosmetics are PE and also they can be composed of PP, PET, PMMA and nylon (Eriksen et al., 2013). The MP particles found in many personal care and cosmetic products are used daily throughout the world. MP particles and other plastic wastes generated as a result of use complete the journey after receiving wastewater treatment plants in receiving environments (Carr et al., 2016).

Due to their hydrophobic properties, MPs tend to absorb on organic materials and organic contaminants present in the aqueous medium (Carr et al., 2016). These pollutants reach humans through the food chain through MPs. 
Plastic size classification

\begin{tabular}{|c|c|c|}
\hline $\begin{array}{l}<1 \mu \mathrm{m} \\
\text { Nanoplastic }\end{array}$ & $\begin{array}{r}1 \mu \mathrm{m}-5 \mathrm{~mm} \\
\text { Microplastic }\end{array}$ & $\begin{array}{c}5 \mathrm{~mm}-200 \mathrm{~mm} \\
\text { Mesoplastic }\end{array}$ \\
\hline
\end{tabular}

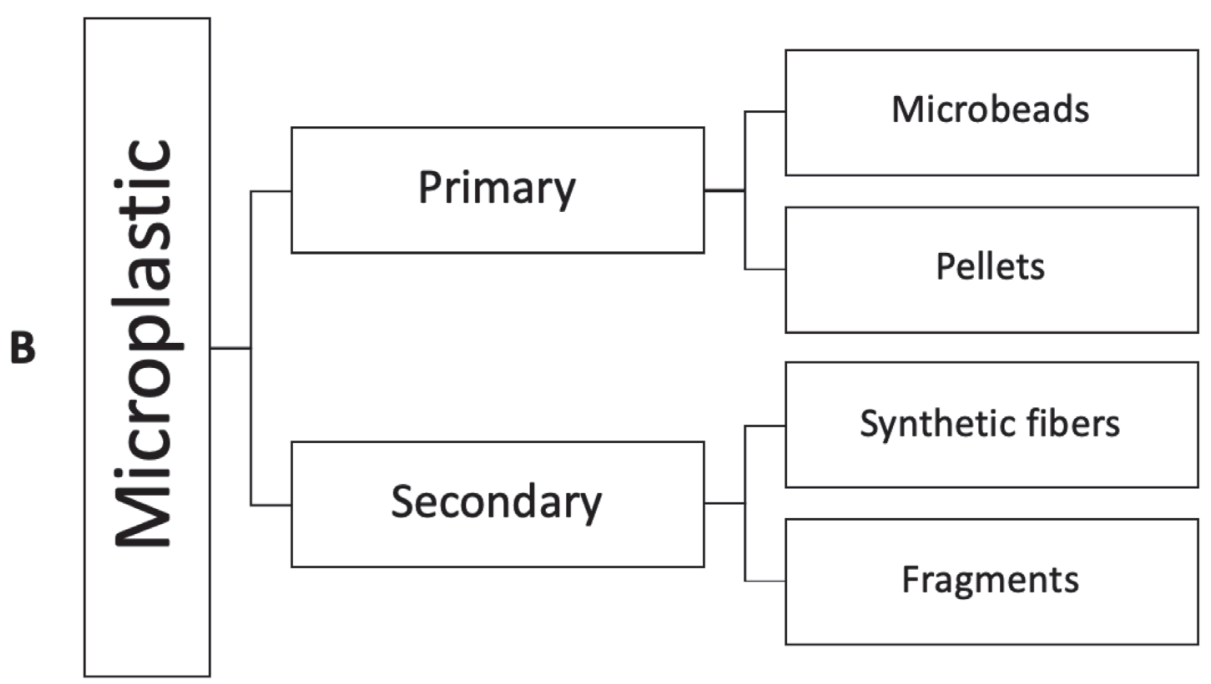

Figure 1. Classification, origins of microplastics (Germanov et al. 2018).

\section{Microplastics in Environment}

MPs can be transported for a long distance by atmosperic movements and settled down into the aquatic or terrestrial environment (Akdoğan \& Güven, 2019; Dris et al., 2016). Therefore, MPs can be measured in marine (Eriksen et al., 2014), sediments (Zhang et al., 2020), lakes (Zhang et al., 2016) and rivers (Moore et al., 2011). Amount of the MPs in the different environments can be affected by wind velocity and runoff (Zhang, 2017). MPs are also released from wastewater treatment plants (WWTP) to the aquatic environments (Akarsu et al., 2020; Browne et al., 2011).

\section{Marine environment.}

MPs can be found in all the collected samples from the surface to the deep sea or ocean. MPs have been reporting in marine samples at the first time in early 1970s (Carpenter \& Smith, 1972). MPs broken down into the smaller pieces due to physical, biological and chemical processes can be transffered directly or indirectly to seas and oceans (Lozano \& Mouat, 2009). Ultraviolet (UV) radiation plays an important role 
in plastic fragmentation at marine environment. Fragmentation rate depends on the temperature, polymer type, additives and fillers (Andrady et al., 2003).

Plastics in the marine environment are of ship and terrestrial origin and a significant proportion of terrestrial plastics are transported from rivers to the sea (Lechner et al., 2014). Another important plastic input into the marine environment is through MPs that flow from the home and industrial products to the sewer systems and flow into the sea (Xu et al., 2020). The recovery rate of plastics materials is less than $5 \%$, causing the rapid accumulation of plastics in marine environments (Sutherland et al., 2010).

The amount of primary microplastic in the marine environment is reported to be less than that of secondary microplastics (Ryan, 2015). Fibers are the most common form of MP in the marine environment (Wright et al., 2013). Fibers, an important source of MP, are caused by laundry washing. A study measuring MP concentration in 18 regions around the world has shown that a single garment can produce $>1900$ fibers per wash (Browne et al., 2011). Natural textile or synthetic textile fibers can be found in marine environment (Almroth et al., 2018).

Significant amounts of MP deposits accumulate in deep seas and MPs are found everywhere in sea sediments (Woodall et al., 2014). MPs abundance can be affected by distance from the coastline and the sediment depth (Xu et al., 2020). For $20 \mathrm{~m}$ to $80 \mathrm{~m}$ sediment depth, measured MPs increased from 1765 to 2771 particles $/ \mathrm{kg}$ dry weight. The results proved that more accumulation of MPs were observed in deeper sediments (Wang et al., 2019).

Due to the nature of small particles in micron size, it can be swallowed by sea creatures as food. Starting from phytoplanktons, microplastics can be transferred through zooplanktons, sea urchins, lobsters, and ultimately to the higher tropical level via the food chain (Chatterjee \& Sharma, 2019). Ingestion can upset the animals' energy balance, affect behaviour, or even block the intestinal tract resulting in severe sub-lethal effects or even death (Kühn et al., 2015). It is reported that approximately 700 marine organism species encounter marine waste and $92 \%$ of this encounter is plastic waste (Gall \& Thompson, 2015).

As a result of numerous studies, it has been reported that MPs are ingested by various sea creatures such as zooplankton (Desforges et al., 2015; Sun et al., 2017), mussels (Cauwenberghe et al., 2015; Li et al., 2016), coral (Salonu et al., 2015), fish (Neves et al., 2015; Jabeen et al., 2017). MPs were found approximately $20 \%$ of 
263 fish samples which are $66 \%$ of fiber and $34 \%$ of particles (Neves et al., 2015). Approximately $35 \%$ of the fish examined had plastic pieces in their guts in the North Pacific Central Gyre. A total of 1375 pieces of plastic, averaging 2.1 pieces $( \pm 5.78)$ per fish, were collected from fish guts. Based on another study, a total of 141 fishes from 27 species and 4 families were examined and plastic items were found inside the stomachs of 13 fishes, this is equal to $9.2 \%$ of the fishes sampled throughout the study (Davison \& Asch, 2011).

Based on the previous study, conducted in Turkey's Mediterranean coast, 28 species of fish in 1337, the presence of the MP was investigated. MP was detected in $58 \%$ of the fish. $70 \%$ of ingested plastics are fiber and $20.8 \%$ are hard plastics. In addition, the amount of MP was determined by taking water and sediment samples from the same region. It was determined that $94 \%$ of MPs in water and sediment samples were between 0.1-2.5 $\mathrm{mm}$ in size (Güven et al., 2017).

MPs have been recognized as transport vectors for micropollutants. Rochman et al. (2013b) reported that as a result of microplastics ingested by fish, PBDE accumulation was observed in its tissues.

Plastic particles (3-9.6 $\mu \mathrm{m}$ ) ingested by mussels (Mytilus edulis) accumulated in the digestive tissues and carried into the circulatory system (Browne et al., 2008). It is estimated that blue whales (Balaenoptera musculus), the largest animal in the world, received and hold MP in their body as a result of eating plankton (Yurtsever, 2014).

\section{River basin.}

MPs at the river samples in California were reported at the first time in 2011 (Moore et al., 2011). River plays an important role in the transportation of MPs. Aproximately $80 \%$ of MPs in sea was transffered by the rivers (Akdoğan \& Güven, 2019). Moore et al. (2011) reported that 30 million tonnes of MPs released from the Los Angeles and San Gabriel Rivers into the marine environment in a $72 \mathrm{~h}$. In another study, it was estimated that up to 2.5 million tonnes of MPs released into the ocean by the rivers each year (Lebreton et al., 2017). It is estimated that the plastic input to the Black Sea via the Danube River is 4.2 tons/day (Lechner et al., 2014).

The effects of municipal and industrial wastewater discharges on surface water and MP concentration in sediment have been investigated by various studies (Castaneda et al., 2014; Vermaire et al., 2017; Klein et al., 2015; Estahbanati \& 
Fahrenfeld, 2016). Based on the previous study, it was determined that WWTPs are not the only source in terms of MPs pollution in the fresh water source, but they have negative effects on the receiving environment (Estahbanati \& Fahrenfeld, 2016).

MP ingestion has been confirmed for over 220 species including freshwater invertebrates and fish (Lusher et al., 2017; Peters \& Bratton, 2016). Based on the previous study, MPs was found in the intestines of one third of the fish (Rutilus rutilus species) caught from the River Thames. The MP particle types include fibres (75\%), fragments (22.7\%) and films (2.3\%) (Horton et al., 2018).

\section{Lake environment.}

Studies in freshwater environments have been limited compared to studies in the marine environment. Although fresh waters play an important role in carrying MPs, little is known about them. The first MP investigation in the sediment and surface waters of the West and East Dongting Lake conducted by Jiang et al. (2018). As a result of the study, the highest level of MP pollution was detected in the outlet waters of the lakes. They reported that PS and PET are commonly found in surface water and sediment samples. Faure et al. (2015) evaluated the abundance of MPs in the Swiss lakes, defined the composition of the particles, and examined the fish and birds exposed by the tendency to absorb hydrophobic organic micro-pollutants onto the MPs.

\section{Soil environment.}

Although there are terrestrial MPs, their concentrations and fate in terrestrial environments are not yet fully understood (Scheurer \& Bigalke, 2018). As a result of disposal of all plastics in both terrestrial and adjacent freshwater environments can create intensive plastic pollution and annual plastic emissions to terrestrial environments may be 4-23 times larger than oceans (Horton etal., 2017). Approximately $60 \%$ of produced plastics have been reported to accumulate in landfills or natural environments (Geyer et al., 2017). The abundance, permanence and prevalence of MPs in the soil environment pose a serious environmental risk (Wang et al., 2019).

The input of primary MPs to terrestrial environments is through personal care or by applying sewage sludge containing MPs from the home products to the soil (Habib et al., 1996; Zubris \& Richards, 2005). MPs separated as a result of washing the clothes are found in WWTP sludge and purified wastewater wastes since they are not biodegradable. Zubris and Richards (2005) detected MPs by polarized light microscopy on soils where organic wastewater sludge was applied. The ability to 
detect fibers up to 15 years after application shows the potential permanence in the soil environment. Approximately $50 \%$ of sewage sludge is used in agricultural purpose in Europe and North America, it is estimated that 850 tons of MP is added to European soil annually with sewage sludge application (Nizzetto et al., 2016). As MPs are transported by wind from land, more dense plastic materials are likely to be buried in deep layers and remain in the soil (Horton et al. 2017). Soils are considered as sinks for MPs due to the extremely slow photo-oxidative degradation for macro plastic litter and MPs buried in the soil (Duis \& Coors, 2016). Zhang and Liu (2018) reported that $72 \%$ of the plastic particles in the soil were related to the soil aggregate.

\section{Exposore to Microplastics (MPs)}

The presence of MPs in environments, including consumer products, is an inevitable end to human exposure to MPs. The intake of MPs-contaminated foods, inhalation and skin contact (only nano sized particles) are among the routes of exposure (Prata et al., 2020). Figure 2 shows routes of exposure to MPs and their effects on human health.

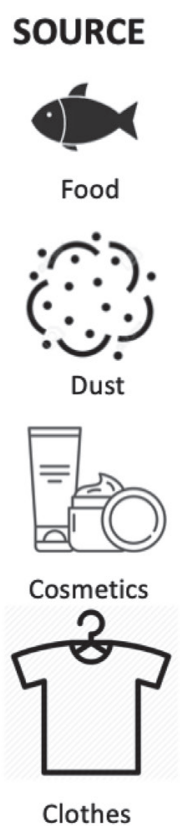

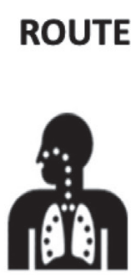
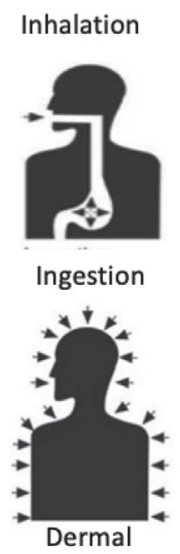

RECEPTOR

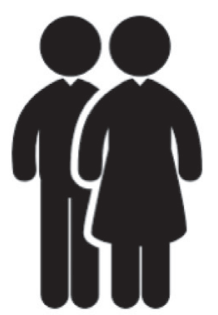

Inflammation

Vascular occlusions

Blood cell cytotoxicity

Cancer

Figure L. Effects of micropiastics on numan health (Prata et al., LU LU).

Ingestion is probably the most common and most important route of exposure 
for people (Prata et al., 2020). Annual MP consumption has been reported to vary between an estimated 39000-52000 particles per person. These estimates may increase from 74000 to 121000 with inhalation (Cox et al., 2019). MPs could be detected at various samples such as mussel, fish, table salt, sugar and bottled water (Karami et al., 2017; Li et al., 2016; Liebezeit \& Liebezeit, 2013; Neves et al., 2015; Oßmann et al., 2018). In a study conducted in China, MP content was found to be 550-681 particles / kg, 43-364 particles / kg, 7-204 particles / kg in sea salt, lake salt and rock / hollow salt respectively. The higher MPs abundance in sea salts is an indication that marine products are also contaminated with MPs (Yang et al., 2015).

MPs in the cirgulation could cause pulmonary hypertension, inflammation, vascular occlusions, blood cell cytotoxicity, and increased coagulability (Prata et al., 2020).

\section{Conclusion and Recommendations}

MP pollution caused by the disintegration of plastics and it has become a global environmental problem. As a result of increasing interest in recent years, studies have shown that MPs are ubiquitous. Excessive use of plastic as a material due to the low cost and functional use and inadequate recycling pose a threat for ecosystem. Preventing exposure with necessary prohibitions, raising public awareness about MPs sources and giving up disposable plastics will raise awareness on this issue. In recent years, studies on the negative effects of plastic wastes have increased. In many countries, including our country, disposable plastic bag tax was designed to decrease the use of the plastic bags. Because cosmetics also contain MPs, in some countries cosmetics containing microbeads for preventive purposes are prohibited. It is known that the pollutants of MPs in the aquatic environment are transported to the living organisms via the food chain as vectors. Consequently, studies should be carried out in order to prevent excessive plastic consumption in terms of protection of water resources, units to hold these pollutants in treatment plants should be added and measures should be taken for better management of these wastes.

According to the results of the literature review, there are many studies carried out in the marine environment. It is recommended to increase the number of studies on pollution caused by MPs in the river, lake and soil environment. 


\section{References}

Akarsu, C., Kumbur, H., Gökdağ, K., Kıdeyş, A. E. \& Sanchez-Vidal, A. (2020). Microplastics composition and load from three wastewater treatment plants discharging into Mersin Bay, north eastern Mediterranean Sea. Marine Pollution Bulletin, 150, 110776. https://doi.org/10.1016/j. marpolbul.2019.110776

Akdoğan, Z. \& Güven, B. (2019). Microplastics in the environment: A critical review of current understanding and identification of future research needs. Environmental Pollution, 254, 113011. https://doi.org/10.1016/j.envpol.2019.113011

Almroth, B. M. C., Aström, L., Roslund, S., Petersson, H., Johansson, M., \& Persson, N-K. (2018). Quantifying shedding of synthetic fibers from textiles; a source of microplastics released into the environment. Environmental Science and Pollution Research, 25(2), 1191-1199. https://doi. org/10.1007/s11356-017-0528-7

Andrady, A. L., Hamid, H. S., \& Torikai, A. (2003). Effects of climate change and UV-B on materials. Photochemical and Photobiological Sciences, 2, 68-72. https://doi.org/10.1039/B211085G

Auto, H. S., Emenike, C. U., \& Fauziah, S. H. (2017). Distribution and importance of microplastics in the marine environment: A review of the sources, fate, effects, and potential solutions. Environment International, 102, 165-176. https://doi.org/10.1016/j.envint.2017.02.013

Barnes, D. K. A., Galgani, F., Thompson, R. C., \& Barlaz, M. (2009). Accumulation and fragmentation of plastic debris in global environments. Philosophical Transactions of The Royal Society B, 364(1526), 1985-1998. https://doi.org/10.1098/rstb.2008.0205

Boerger, C. M., Lattin, G. L., Moore, S. L., \& Moore, C. (2010). Plastic ingestion by planktivorous fishes in the North Pacific Central Gyre, Marine Pollution Bulletin, 60(12), 2275-2278. https://doi. org/10.1016/j.marpolbul.2010.08.007

Browne, M. A., Dissanayake, A. Galloway, T. S., Lowe, D. M., \& Thompson, R. C. (2008). Ingested Microscopic Plastic Translocates to the Circulatory System of the Mussel, Mytilus edulis (L.), Environmental Science \& Technology, 42(13), 5026-5031. https://doi.org/10.1021/es800249a

Browne, M. A., Crump, P., Niven, S. J., Teuten, E., Tonkin, A., Galloway, T., \& Thompson, R. (2011). Accumulation of Microplastic on Shorelines Woldwide: Sources and Sinks. Environmental Science \& Technology, 45(21), 9175-9179. https://doi.org/10.1021/es201811s

Carpenter, E.J., \& Smith, K.L. (1972). Plastics on the Sargasso Sea Surface, 1240-1241.

Carr, S. A., Liu, J., \& Tesoro, A. G. (2016). Transport and fate of microplastic particles in wastewater treatment plants. Water Research, 91, 174-182. https://doi.org/10.1016/j.watres.2016.01.002

Castaneda, R. A., Avlijas, S., Simard, M. A., \& Ricciardi, A. (2014). Microplastic pollution in St. Lawrence river sediments, Canadian Journal of Fisheries and Aquatic Sciences, 71, 1767-1771. https://doi.org/10.1139/cjfas-2014-0281 
Cauwenberge, L. V., Claessens, M., Vandegehuchte, M. B., \& Janssen C. R. (2015). Microplastics are taken up by mussels (Mytilus edulis) and lugworms (Arenicola marina) living in natural habitats, Environmental Pollution, 199, 10-17. https://doi.org/10.1016/j.envpol.2015.01.008

Chatterjee, S., \& Sharma, S. (2019). Microplastics in our oceans and marine health. Field Actions Science Reports The journal of field actions, (Special Issue 19), 54-61. DOI: 10.1007/s11356-0179910-8

Cox, K. D., Covernton, G. A., Davies, H. L., Dower, J. F., Juanes, F., \& Dudas, S. E. (2019). Human Consumption of Microplastics. Environmental Science and Technology, 53(12), 7068-7074. https:// doi.org/10.1021/acs.est.9b01517

Davison, P., \& Asch, R. (2011). Plastic ingestion by mesopelagic fishes in the North Pacific Subtropical Gyre. Mar Ecol Prog Ser, 432, 173-180. DOI: 10.3354/meps09142

Dehghani, S., Moore, F. \& Akhbarizadeh, R. (2017). Microplastic pollution in deposited urban dust, Tehran metropolis, Iran. Environmental Science and Pollution Research, 24(25), 20360-20371. DOI: $10.1007 / \mathrm{s} 11356-017-9674-1$

Desforges, J-P. W., Galbraith, M., Dangerfield, N., \& Ross, P. S. (2014). Widespread distribution of microplastics in subsurface seawater in the NE Pacific Ocean. Marine Pollution Bulletin 79(1-2), 94-99. https://doi.org/10.1016/j.marpolbul.2013.12.035

Desforges, J-P. W., Galbraith, M., \& Ross, P. S. (2015). Ingestion of Microplastics by Zooplankton in the Northeast Pacific Ocean. Archives of Environmental Contamination and Toxicology, 69, 320-330. https://doi.org/10.1007/s00244-015-0172-5

Dris, R., Gasperi, J., Saad, M., Mirande, C., \& Tassin, B. (2016). Synthetic fibers in atmospheric fallout: A source of microplastics in the environment? Marine Pollution Bulletin, 104(1-2), 290293. https://doi.org/10.1016/j.marpolbul.2016.01.006

Duis, K., \& Coors, A. (2016). Microplastics in the aquatic and terrestrial environment: sources (with a specific focus on personal care products), fate and effects. Environmental Sciences Europe, 28, 2. https://doi.org/10.1186/s12302-015-0069-y

Eriksen, M., Mason, S., Wilson, S., Box, C., Zellers, A., Edwards, W., ... Amato, S. (2013). Microplastic pollution in the surface waters of the Laurentian Great Lakes. Marine Pollution Bulletin, 77(1-2), 177-182. http://doi.org/10.1016/j.marpolbul.2013.10.007

Eriksen, M., Lebreton, L. C. M., Carson, H. S., Thiel, M., Moore, C. J., Borerro, J. C., ... Reisser, J. (2014). Plastic Pollution in the World's Oceans: More than 5 Trillion Plastic Pieces Weighing over 250,000 Tons Afloat at Sea. Plos One, 9(12), e111913. https://doi.org/10.1371/journal. pone. 0111913

Estahbanati, Ş., \& Fahrenfeld, N. L. (2016). Influence of wastewater treatment plant discharges on microplastic concentrations in surface water. Chemosphere, 162, 277-284. https://doi.org/10.1016/j. chemosphere.2016.07.083 
Faure, F., Demars, C., Wieser, O., Kunz, M., \& de Alencastro, L. F. (2015). Plastic pollution in Swiss surface waters: nature and concentrations, interaction with pollutants. Environmental Chemistry, 12(5), 582-591. https://doi.org/10.1071/EN14218

Gall, S. C., \& Thompson, R. C. (2015). The impact of debris on marine life. Marine Pollution Bulletin, 92(1-2), 170-179. https://doi.org/10.1016/j.marpolbul.2014.12.041

Germanov, E. S., Marshall, A. D., Bejder, L., Fossi, M. C., \& Loneragan, N. R. (2018). Microplastics: No Small Problem for Filter-Feeding Megafauna. Trends in Ecology \& Evolution, 33(4), 227-232. https://doi.org/10.1016/j.tree.2018.01.005

Geyer, R., Jambeck, J. R., \& Law, K. L. (2017). Production, use, and fate of all plastics ever made. Science Advances, 3(7), e1700782. DOI: 10.1126/sciadv.1700782

Güven, O., Gökdağ, K., Jovanovic, B., \& Kıdeyş, A. E. (2017). Microplastic litter composition of the Turkish territorial waters of the Mediterranean Sea, and its occurrence in the gastrointestinal tract of fish. Environmental Pollution, 223, 286-294. https://doi.org/10.1016/j.envpol.2017.01.025

Habib, D., Locke, D. C., \& Cannone, L. J. (1996). Synthetic fibers as indicators of municipal sewage sludge, sludge products, and sewage treatment plant effluents. Water, Air and Soil Pollution, 103, $1-8$.

Hopewell, J., Dvorak, R., \& Kosior, E. (2009). Plastics recycling: challenges and opportunities. Philosophical Transactions of the Royal Society B, 364, 2115-2126. https://dx.doi. org/10.1098\%2Frstb.2008.0311

Horton, A. A., Walton, A., Spurgeon, D. J., Lahive, E., \& Svendsen, C. (2017). Microplastics in freshwater and terrestrial environments: Evaluating the current understanding to identify the knowledge gaps and future research priorities. Science of The Total Environment, 586, 127-141. https://doi.org/10.1016/j.scitotenv.2017.01.190

Horton, A. A., Jürgens, M. D., Lahive, E., van Bodeom, P. M., \& Vijyer, M. G. (2018). The influence of exposure and physiology on microplastic ingestion by the freshwater fish Rutilus rutilus (roach) in the River Thames. UK, Environmental Pollution, 236, 188-194. https://doi.org/10.1016/j. envpol.2018.01.044

Jabeen, K., Su, L., Li, J., Yang, D., Tong, C., Mu, J., \& Shi, H. (2017). Microplastics and mesoplastics in fish from coastal and fresh waters of China, Environmental Pollution, 221, 141-149. https://doi. org/10.1016/j.envpol.2016.11.055

Jambeck, J. R., Geyer, R., Wilcox, C., Siegler, T. R., Perryman, M., Andrady, A., ... Law, K. L. (2015). Plastic waste inputs from land into the ocean. Science, 347(6223), 768-771. DOI: 10.1126/ science. 1260352

Jiang, C., Yin, L., Wen, X, Chunyan, D., Wu, L., Long, Y., ... Pan, H. (2018). Microplastics in Sediment and Surface Water of West Dongting Lake and South Dongting Lake: Abundance, Source and Composition. International Journal of Environmental Research and Public Health, 15, 2164. https://dx.doi.org/10.3390\%2Fijerph15102164 
Karami, A., Golieskardi, A., Choo, C. K., Larat, V., Galloway, T. S., \& Salamatinia, B. (2017). The presence of microplastics in commercial salts from different countries. Scientific Reports, 7, 46173. https://dx.doi.org/10.1038\%2Fsrep46173

Klein, S., Worch, E., \& Knepper, T. P. (2015). Occurrence and spatial distribution of microplastics in river shore sediments of the Rhine-Main Area in Germany, Environmental Science \& Technology, 49(10), 6070-6076. https://doi.org/10.1021/acs.est.5b00492

Kühn, S., Rebolledo, E.L.B., \& van Franeker, J.A. (2015). Deleterious effects of litter on marine life. In: Marine Anthropogenic Litter. Springer Publishers, New York, USA.

Lebreton, L. C. M., van der Zwet, J., Damsteeg, J-W., Slat, B., Andrady, A., \& Reisser, J. (2017). River plastic emissions to the world's oceans. Nature Communications, 8,15611 . https://dx.doi. org/10.1038\%2Fncomms 15611

Lechner, A., Keckeis, H., Lumesberger-Loisi, F., Zens, B., Krusch, R., Tritthart, M., ... Schludermann, E. (2014). The Danube so colourful: A potpourri of plastic litter outnumbers fish larvae in Europe's second largest river. Environmental Pollution, 188, 177-181. https://dx.doi.org/10.1016\%2Fj. envpol.2014.02.006

Li, J., Qu, X., Su, L., Zhang, W., Yang, D., Kolandhasamy, P., ... Shi, H. (2016). Microplastics in mussels along the coastal waters of China. Environmental Pollution, 214, 177-184. https://doi. org/10.1016/j.envpol.2016.04.012

Liebezeit, G. \& Liebezeit, E. (2013). Non-pollen particulates in honey and sugar. Food Additives \& Contaminants: Part A, 30(12), 2136-2140. https://doi.org/10.1080/19440049.2013.843025

Liu, X., Yuan, W., Di, M., Li, Z., \& Wang, J. (2019). Transfer and fate of microplastics during the conventional activated sludge process in one wastewater treatment plant of China. Chemical Engineering Journal, 362, 176-182. https://www.X-mol.com/paperRedirect/953045

Lozano, R. L., \& Mouat, J. (2009). Marine litter in the North-East Atlantic Region: Assessment and priorities for response. KIMO International.

Lusher et al. 2017 makalede yer alan bu referans ilave edilmeli

Mintenig, S. M., Int-Veen, I., Löder, M. G. J., Primpke, S., \& Gerdts, G. (2017). Identification of microplastic in effluents of waste water treatment plants using focal plane array-based microFourier-transform infrared imaging. Water Research, 108, 365-372. https://doi.org/10.1016/j. watres.2016.11.015

Moore, C. J., Lattin, G. L., \& Zellers, A. F. (2011). Quantity and type of plastic debris flowing from two urban rivers to coastal waters and beaches of Southern California. Journal of Integrated Coastal Zone Management, 11(1), 65-73. DOI: 10.5894/rgci194

Neves, D., Sobral, P., Ferreira, J. L., \& Pereira, T. (2015). Ingestion of microplastics by commercial fish off the Portuguese coast. Marine Pollution Bulletin, 101(1), 119-126. https://doi.org/10.1016/j. marpolbul.2015.11.008 
Nizzetto, L., Futter, M., \& Langaas, S. (2016). Are Agricultural Soils Dumps for Microplastics of Urban Origin? Environmental Science and Technology, 50(20), 10777-10779. https://doi.org/10.1021/ acs.est.6b04140

Ngo, P. L., Pramanik, B. K., Şah, K., \& Roychand, R. (2019). Pathway, classification and removal efficiency of microplastics in wastewater treatment plants. Environmental Pollution, 255(Pt 2), 113326. https://doi.org/10.1016/j.envpol.2019.113326

Oßmann, B. E., Sarau, G., Holtmannspötter, H., Pischetsrieder, M., Christiansen, S. H., \& Dicke, W. (2018). Small-sized microplastics and pigmented particles in bottled mineral water. Water Research, 141, 307-316. https://doi.org/10.1016/j.watres.2018.05.027

Pardos Marketing. (2019). Retrieved September, 9, 2019 from https://www.pardos-marketing.com/ hot04.htm

Peters, C. A., \& Bratton, S. P. (2016). Urbanization is a major influence on microplastic ingestion by sunfish in the Brazos River Basin, Central Texas, USA, Environmental Pollution, 210, 380-387. https://doi.org/10.1016/j.envpol.2016.01.018

Prata, J. C., da Costa, J. P., Lopes, I., Duarte, A. C., \& Rocha- Santos, T. (2020). Environmental exposure to microplastics: an overview on possible human health effects. Scince of The Total Environment, 702, 134455. https://doi.org/10.1016/j.scitotenv.2019.134455

Rochman, C. M., Browne, M. A., Halpern, B. S., Hentschel, B. T., Hoh, E., Karapanagioti, ... Thompson, R. C. (2013a). Classify plastic waste as hazardous. Macmillan Publishers Limited. 494, 169-171. https://doi.org/10.1038/494169a

Rochman, M. C., Hoh, E., Kurobe, T., \& Teh, S. J. (2013b). Ingested plastic transfers hazardous chemicals to fish and induces hepatic stress, Scientific Reports, 3, 32-63. https://doi.org/10.1038/ srep03263

Ryan, P. G. (2015). A brief history of marine litter research. In Marine anthropogenic litter, 1-25. Retrieved hangi tarihte alıntı yapıldıysa örneğin july,10,2020 from web adresi girilsin.

Salonu, N. M., Berry, K. L. E., Rintoul, L., \& Hoogenboom, M. O. (2015). Microplastic ingestion by scleractinian corals, Marine Biology, 162, 725-732. DOI 10.1007/s00227-015-2619-7

Scheurer, M., \& Bigalke, M. (2018). Microplastics in Swiss Floodplain Soils. Environmental Science \& Technology, 52(6), 3591-3598. https://doi.org/10.1021/acs.est.7b06003

Sun, X., Li, Q., Zhu, M., Liang, J., Zheng, S., \& Zhao, Y. (2017). Ingestion of microplastics by natural zooplankton groups in the northern South China Sea, Marine Pollution Bulletin, 115(1-2), 217224. https://doi.org/10.1016/j.marpolbul.2016.12.004

Sun, J., Dai, X., Wang, Q., van Loosdrecht, M. C. M., \& Ni, B-J. (2019). Microplastics in wastewater treatment plants: Detection, occurrence and removal. Water Research, 152, 21-37. https://doi. org/10.1016/j.watres.2018.12.050 
Sutherland, W. J., Clout, M., Cote, I. M., Daszak, P., Depledge, M. H., Fellman, L., ... Watkinson, A. R. (2010). A horizon scan of global conservation issues for 2010. Tends in Ecology \& Evolution, 25(1), 1-7. https://doi.org/10.1016/j.tree.2009.10.003

Thompson, R. C., Swan, S. H., Moore, C. J., \& vom Saal, F. S. (2009). Our plastic age. Philosophical Transactions of the Royal Society, 364, 1973-1976. https://doi.org/10.1098/rstb.2009.0054

Vermaire, J. C., Pomeroy, C., Herczegh, S. M., Haggart, O., \& Murphy, M. (2017). Microplastic abundance and distribution in the open water and sediment of the Ottawa River, Canada, and its tributaries, Facets, 2, 301-314. http://dx.doi.org/10.1139/facets-2016-0070

Wang, J., Tan, Z., Peng, J., Qiu, Q.ş \& Li, M. (2016). The behaviors of microplastics in the marine environment, Marine Environmental Research, 113, 7-17. https://doi.org/10.1016/j. marenvres.2015.10.014

Wang, J., Wang, M., Ru, S., \& Liu, X. (2019). High levels of microplastic pollution in the sediments and benthic organisms of the South Yellow Sea, China. Science of The Total Environment, 651, Part 2, 1661-1669. https://doi.org/10.1016/j.scitotenv.2018.10.007

World Economic Forum. (2016, January 19). 'More Plastic than Fish in the Ocean by 2050: Report Offers Blueprint for Change. Retrieved June, 02, 2020 from https://www.weforum.org/press/2016/01/more-plastic-than-fish-in-the-ocean-by-2050-reportoffers blueprint-for-change/

Woodall, L. C., Sanchez-Vidal, A., Canals, M., Paterson, G. L. J., Coppock, R., Sleight, V., ... Thompson, R. C. (2014). The deep sea is a major sink for microplastic debris. Royal Society Open Science, 1(4), 140317. https://doi.org/10.1098/rsos.140317

Wright, S. L., Thompson, R. C., \& Galloway, T. S. (2013). The physical impacts of microplastics on marine organisms: A review. Environmental Pollution, 178, 483-492. https://doi.org/10.1016/j. envpol.2013.02.031

World Wildlife Fund-Türkiye. (2018). Akdeniz'deki Plastik Kapan. Retrieved September, 09, 2019 fromhttps://d2hawiim0tjbd8.cloudfront.net/downloads/plastik_raporu_web_icin_2.pdf

Xu, S., Ma, J., Ji, R., Pan K., \& Miao, A-J. (2020). Microplastics in aquatic environments: Occurrence, accumulation, and biological effects. Science of The Total Environment, 703, 134699. https://doi. org/10.1016/j.scitotenv.2019.134699

Yang, D., Shi, H., Li, L., Li, J., Jabeen, K., \& Kolandhasamy, P. (2015). Microplastic Pollution in Table Salts from China. Environmental Science and Technology, 49(22), 13622-13627. https://doi. org/10.1021/acs.est.5b03163

Yurtsever, M. (2014). Mikroplastikler'e Genel Bir Bakış. Dokuz Eylül Üniversitesi Mühendislik Fakültesi Fen ve Mühendislik Dergisi, 17(50), 68-83. Retrieved hangi tarihte alıntı yapıldıysa tarih girilecek from http://web.deu.edu.tr/fmd/s50/S50-m3.pdf

Zhang, K., Su, J., Xiong, X., Wu, X., Wu, C., \& Liu, J. (2016). Microplastic pollution of lakeshore sediments from remote lakes in Tibet plateau, China. Environmental Pollution, 219, 450-455. https://doi.org/10.1016/j.envpol.2016.05.048 
Zhang, H. (2017) Transport of microplastics in coastal seas. Estuarine, Coastal and Shelf Science, 199, 74-86. https://doi.org/10.1016/j.ecss.2017.09.032

Zhang, G. S., \& Liu, Y. F. (2018). The distribution of microplastics in soil aggregate fractions in southwestern China. Science of The Total Environment, 642, 12-20. https://doi.org/10.1016/j. scitotenv.2018.06.004

Zhang, D., Cui, Y., Zhou, H., Jin, C., Yu, X., Xu, Y., Li, Y., \& Zhang, C. (2020). Microplastic pollution in water, sediment, and fish from artificial reefs around the Ma'an Archipelago, Shengsi, China. Science of The Total Elvironment, 703, 134768. https://doi.org/10.1016/j.scitotenv.2019.134768

Zhao, S., Zhu, L., \& Li, D. (2015). Microplastic in three urban estuaries, China. Environmental Pollution, 206, 597-604. DOI: 10.1016/j.envpol.2015.08.027

Zubris, K. A. V., \& Richards, B. K. (2005). Synthetic fibers as an indicator of land application of sludge. Environmental Pollution, 138(2), 201-211. https://doi.org/10.1016/j.envpol.2005.04.013 


\section{Extended Turkish Abstract (Genişletilmiş Türkçe Özet)}

\section{Çevresel Ortamlarda Mikroplastikler ve Canlılara Etkileri}

Plastikler hafif, ucuz ve kolay işlenebilir olması sebebiyle çok farklı alanlarda (paketleme, otomotiv, inşaat, elektrik vd.) kullanılmaktadır. Yüksek 1sı ve elektriksel yalıtım özelliklerine sahip, güçlü, ve korozyona dayanıklı olmaları sebebiyle çok yönlü malzemelerdir. Bu özelliklerinden dolayı günümüzün vazgeçilmez ürünü haline gelmiştir. Plastik üretimi ve buna bağlı olarak tüketimi katlanarak her geçen gün ciddi oranlarda artmaktadır. Üretilen plastiklerin tek kullanımlık ambalaj malzemelerinde ve kısa ömürlü ürünlerde kullanılması plastik kullanımının sürdürülebilir olmadığının bir kanıtıdır. Insanların bilinçsiz kullanımı, sürdürülebilir olmayan tek kullanımlık uygulamalar ve uygun olmayan atık yönetimi, alıcı ortamlarda yoğun bir plastik birikimine neden olmakta ve beraberinde çevre kirliliğini de getirmektedir.

Üretilen bu plastikler doğada ki yolculuğunu deniz ortamında tamamlarlar. Yetersiz atık yönetiminden dolayı büyük miktarlarda plastik kara ortamından okyanuslara girmektedir. Dolayısıyla gelişmemiş ülkelerde mikropastik kirliliği daha fazladır. Plastik malzemelerden geri kazanım oranının düşük olması sebebiyle deniz ortamında plastiklerin hızla birikmesine neden olmaktadır. Günümüzde plastik ayak izi giderek daha da büyümektedir. Plastik atıklar uygun ve güvenli bir şekilde bertaraf edilmediğinde çevresel ortamlarda birikerek karasal ve sucul ortamlar için ciddi bir tehdit oluşturmaktadırlar. Hatta bazı projeksiyon çalışmalarında 2050 yılına gelindiğinde plastiklerin okyanus ortamındaki balık stoklarının ağırlıklarını aşacağı öngörülmektedir.

Plastiklerin su, rüzgar ve diğer çevresel etmenler gibi farklı süreçlerle parçalanması sonucu 5 mm'den küçük boyutlu olan ve mikroplastikler olarak bilinen parçacıklar oluşur. Mikroplastikler kaynaklarına göre birincil ve ikincil olmak üzere iki sınıfa ayrılır. Birincil mikroplastikler kozmetik ve tıbbi ilaçlarda bulunan polipropilen, polietilen ve polistiren parçacıklarını içerirken, ikincil mikroplastikler daha büyük plastik parçacıkların rüzgar, su ve diğer çevresel etmenler gibi farklı süreçlerle parçalanması sonucu oluşurlar. Kısaca birincil kaynaklar yıkayıcılar, aşındırıcılar ve peletler gibi kasıtlı olarak üretilmiş olup ikincil kaynaklar ise fragmanlar ve lifler gibi daha büyük parçaların bozulması sonucu oluşurlar.

Plastik parçacıkların parçalanması sonucu oluşan mikroplastik kirliliği küresel bir çevre sorunu haline gelmiştir. Son on yılda mikroplastik kaynaklı çevre sorunları ve bu konu hakkında yapılan çalışmalar ilgi odağı olmaya başlamıştır. Bu çalışma kapsamında incelenen makalelerle mikroplastiklerle ilgili bilimsel literatürün gözden geçirilmesi ve insan sağlığına olan etkilerinin derlenmesi amaçlanmıştır.

Atmosferik serpintinin önemli bir mikroplastik kaynağı olduğu bildirilmiştir. Atmosfer ortamında bulunan bu parçacıklar rüzgarlar ile su ortamına taşınabilir veya karasal ortamlarda birikebilir. Rüzgar, sel, gelgitler ve yüzeysel akış gibi fiziksel etkenler mikroplastiklerin farklı çevresel ortamlardaki dağılımını etkilemektedir. Yapılan çalışmalar mikroplastiklerin deniz, göl sediment toprak, nehir ve atmosfer gibi çeşitli ortamlarda bulunduklarını kanıtlamıştır. Atıksu arıtma tesisleri de sucul ortamlar için önemli bir mikroplastik kaynağı olarak bildirilmiştir. Kişisel bakım ve kozmetik ürünlerinin çoğunda mikroplastik parçacıkları bulunmaktadır. Ve bu ürünler tüm dünyada günlük 
olarak çok fazla kişi tarafından kullanılmaktadır. Kullanım sonucunda oluşan mikroplastik parçacıklar ve plastik atıklar yolculuğunu kentsel atıksu arıtma tesislerinden sonra alıcı ortamlarda tamamlarlar. Mikroplastiklerin farklı kaynaklardan alıcı ortamlara karışması sonucu suda yaşayan canlılar, çevre ve insanlar için tehdit oluşturmaktadır.

Nehirler plastik taşınımında önemli bir rol oynamaktadırlar ve karasal plastiğin önemli bir kısmı nehirler aracılığıyla denizlere taşınmaktadır. Lifler deniz ortamında en çok bulunan tekstil kaynaklı mikroplastik türüdür. Önemli bir mikroplastik kaynağı olan elyaf çamaşır yıkanmasından kaynaklanmaktadır. Plastiklerin yutulması sonucunda hayvanların enerji dengesini bozabilir, davranışlarını etkileyebilir ve bağırsaklarını tıkayarak ölümlerine neden olabilir. Tarımsal uygulamalarda arıtma çamurunun kullanılması ile toprak ortamına mikroplastik ilavesi yapıldığı bilinmektedir. Ayrıca mikroplastikler karadan rüzgarla taşınırken daha yoğun plastikler toprağın daha derin katmanlarına gömülerek kalması muhtemeldir.

Mikroplastiklerin hidrofobik yapıda olmaları nedeniyle sucul ortamda bulunan diğer organik kirletici maddelerle birlikte PBDE'leri, endokrin bozucu bileşikleri, kişisel bakım ürünleri ve ilaçları absorme etme eğilimi gösterirler. Mikroplastikler çevresel ortamlarda olduğu kadar canlı yaşamı için de kaygı uyandıran kirleticilerdir. Mikroplastikleri yutan canlılar tarafindan bu kirleticiler besin zinciri yoluyla insanlara kadar ulaşmaktadır. Yapılan çalışmalar ile mikroplastiklerin balık, midye, sofra tuzu, şeker ve şişelenmiş sularda olduğu bildirilmiştir. Mikroplastiklerin çevresel ortamlar ve tüketici ürünler gibi her yerde olması sonucunda insanların mikroplastiklere maruz kalması kaçınılmaz bir durumdur. Mikroplastik içiren gıdaları yeme, havanın solunması ve dermal temas gibi yollarla maruz kalınmaktadır. Bu maruz kalmanın sonucu olarak parçacık toksisitesi, oksidatif stres, iltihap, translokasyon ve kanser gibi çeşitli insan sağlığına etkileri bulunmaktadır.

Plastiklerin ucuz, dayanıklı, hafif ve işlevsel olmasından dolayı gereğinden fazla kullanımı ve yetersiz geri dönüşümü sonucu önemli bir ekolojik tehdit oluşturmaktadır. Son yıllarda plastik atıkların olumsuz etkileri üzerine artan çalışmalar beraberinde gerekli tedbirleri de getirmiştir. Ülkemizin de dahil olduğu bir çok ülkede tek kullanımlık plastik poşetlerin ücretli hale getirilmesiyle aşırı plastik tüketiminin önüne geçilmeye çalışılmaktadır. Ayrıca bazı ülkelerde tedbir amaçlı mikroplastik içeren kozmetik ürünlerde yasaklanmıştır. Gerekli yasaklamalar ile aşırı tüketimin önüne geçilmesi ve halkın biliçlendirilmesi bu konuya olan farkındalı̆̆ arttıracaktır. Su kaynaklarının korunması ve sürdürülebilir bir yaşam için gereğinden fazla plastik tüketiminin önüne geçilmeli, arıtma tesislerine bu kirletici tutacak üniteler ilave edilmeli ve plastik atıkların daha iyi bir atık yönetim planı ile yönetilmesi için gerekli önlemler alınmalıdır. 